„Przekłady Literatur Słowiańskich”. T. 9, cz. 3 ISSN 2353-9763 (wersja elektroniczna)

DOI 10.31261/PLS.2019.09.03.15

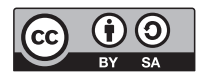

\title{
Bibliografia przekładów literatury polskiej w Serbii w 2017 roku
}

\section{The Bibliography of Translations of Polish Literature in Serbia in 2017}

\section{Estera Sobalkowska}

iD https://orcid.org/0000-0002-1979-0909

UNIVERSITY OF SILESIA IN KATOWICE

estasoba@gmail.com 


\section{Publikacje książkowe}

1. Augustyniak Anna: Bez Ciebie / Bez tebe.

Prev. Rade Tan a sijević. Kraljevo,

Narodna Biblioteka „Stefan Prvovenčani”, 2017, 45 s. [poezja].

2. Dymowski Eligiusz: Po drugiej stronie słowa / S druge strane reči (pesme). Prev. Olga L a i ć K r o w i cka. Požega, Svitak - izdavačka radionica Književnog društva „Razvigor”, 2017, 70 s. [poezja].

3. Głowacki Janusz: Fortynbras się upił / Fortinbras se napio.

Prev. Zoran Đ e r i ć. Novi Sad, Srpsko narodno pozorište, 2017, 16 s. ${ }^{1}$

4. Gombrowicz Witold: Kosmos / Kosmos.

Prev. Biserka R a j č i ć. Novi Sad, Prometej, 2017, 229 s. [proza].

5. Herling-Grudziński Gustaw: O cemu je pisao Franc Kafka².

Prev. Biserka R a j č i ć. Vršac, Književna opština, 2017, 106 s. [proza].

6. Krupska Beata: Sceny z życia smoków / Slike iz života zmajeva.

Prev. Anđela J o č i ć. Beograd, Propolis Books, 2017, 66 s.

[literatura dla dzieci].

7. Lebda Małgorzata: Matecznik / Jezik zemlje.

Prev. Biserka R a j č i ć. Beograd, Treći trg, 2017, 117 s. [poezja].

8. Lem Stanisław: Głos pana / Glas gospodara.

Prev. Petar Vu j i č i ć. Novi Sad, Solaris, 2017, 245 s. [proza].

9. Lem Stanisław: Niezwyciężony / Nepobedivi.

Prev. Petar Vu j i č i ć. Tekst čita: Predrag Mihailović. Beograd,

IP Albatros plus, 2017 [zapis na CD] ${ }^{3}$ [proza].

10. Murek Weronika: Uprawa roślin południowych metodą Miczurina / Uzgoj južnog bilja Mičurinovom metodom.

Prev. Mila G av ri lovi ć. Beograd, Štrik, 2017, 158 s. [proza].

11. Sapkowski Andrzej: Chrzest ognia / Vatreno krštenje.

Prev. Milica M a rki ć. Beograd, Čarobna knjiga, 2017, 366 s. [proza].

12. Sapkowski Andrzej: Narrenturm / Husitska trilogija. Deo 1, Kula ludaka. Prev. Zorana P e r i ć. Beograd, Čarobna knjiga, 2017, 603 s. [proza].

13. Sapkowski Andrzej: Sezon burz / Sezona oluja.

Prev. Zorana L u t o v a c. Izd. 3. Beograd, Čarobna knjiga, 2017, 334 s. [proza].

1 Zapis dzieła w formie katalogowej przygotowanej przez Svetislava Jovanova z ilustracjami Aleksandra Ramadanovicia.

2 Zbiór dzieł G. Herlinga-Grudzińskiego, na który składają się: Godzina cieni, Dziennik pisany noca: 1971-1998; 1989-1996; 1997-2000.

3 Zapis na CD według wersji drukowanej w 2016 roku w tłum. Petara Vujičicia. Płyta składa się z 23 części. 
14. Sienkiewicz Henryk: Hanja / Hania.

Prev. Kristina G av ri lov ski. Beograd, 3D+, 2017, 159 s. [proza].

15. Sienkiewicz Henryk: Janko muzikant i gruge priče.

Prev. Snežana Đu k a n o v i ć. Beograd, Agnosta, 2017, 119 s. [proza].

16. Sienkiewicz Henryk: Quo Vadis? / Quo vadis?.

Prev. Lazar R. K n e ž e v i ć. Sremski Karlovci, Kairos, 2017, 497 s. [proza].

17. Sienkiewicz Henryk: W pustyni i w puszczy / Kroz pustinju i prašumu.

Prev. Svetlana A žd a j e vi ć Pr ot i ć. Beograd, JRJ, 2017, 391 s.

[proza].

18. Sonnenberg Ewa: Imperija suze.

Prev. Biserka R a j č i ć. 2 dopunjeno izd. Beograd, Treći trg, 2017, 148 s. [poezja].

19. Szczygielski Marcin: Czarownica piętro niżej / Čarobnica sa sprata niže. Prev. Anđela J o č i ć. Beograd, Propolis Books, 2017, 305 s. [proza].

20. Szymborska Wisława: Pochwała złego o sobie mniemania / Pohvala lošeg mišljenja o sebi: izabrane pesme.

Prev. Biserka R aj č ić, Petar Vu j i č i ć. Banja Luka, Kuća poezje, 2017, 269 s. [poezja].

21. Terakowska Dorota: Lustro Pana Grymsa / Ogledalo gospodina Grimsa. Prev. Anđela J o č i ć. Beograd, Propolis Books, 2017, 206 s. [proza].

22. Tokarczuk Olga: Księgi Jakubowe albo Wielka podróż przez siedem granic, pięć języków i trzy duże religie, nie licząc tych małych / Knjige Jakovljeve iliti Dugo putovanje preko sedam granica, pet jezika i tri velike religije, ne rečunajući one male, o čemu pripovedaju počivši, a što je autorka nadopunila metodom konjekture, iz mnogovrsnih knjiga crpene, pride potkrepljene imaginacijom, najvećim prirodnim darom čevekovim.

Prev. Milica M a r k i ć. Beograd, Paideia: Službeni glasnik, 2017, 762 s. [proza].

23. Witkiewicz Stanisław Ignacy: Nienasycenie / Nezasitost.

Prev. Biserka R a j či ć. Beograd, Službeni glasnik, 2017, 599 s. [proza].

\section{Publikacje w czasopismach}

1. „Koraci” 2017, sv. 7/9.

\section{Herling-Grudziński Gustaw}

Godzina cieni. Eseje / Strašni sud (Kami, Kafka) [fragmenty].

Izb. i prev. Biserka R a j č i ć, s. 73-85 [proza]. 
2. „Polja: mesečnik za umetnost i kulturu” 2017, br. 503.

Varga Krzysztof

W kraju Morloków / U zemlji Morloka.

Prev. Milica Markić, s. 168-173 [felieton].

ESTERA SOBALKOWSKA | mgr, doktorantka w Zakładzie Teorii Literatury i Translacji Uniwersytetu Śląskiego w Katowicach. Absolwentka studiów licencjackich z rosjoznawstwa, politologii oraz kulturoznawstwa. Jej zainteresowania naukowe koncentrują się wokół literatury serbskiej i przekładu, a także wokół kultury Bałkanów oraz związków serbsko-rosyjskich. Jest autorką m.in. bibliografii literatury polskiej w Serbii za lata 2014-2016 oraz komentarza do bibliografii za rok 2015. 